\title{
Sex- and morph-specific predation risk: Colour or behaviour dependency?
}

\author{
HANS VAN GOSSUM ${ }^{1 *}$, Tim ADRIAENS ${ }^{2}$, HeNRI DUMONT ${ }^{3}$ and RobBy STOKS ${ }^{4}$ \\ ${ }^{1}$ Evolutionary Biology Group, University of Antwerp, Groenenborgerlaan 171, B-2020 Antwerp, Belgium \\ ${ }^{2}$ Institute for Nature Conservation, Kliniekstraat 25, B-1070 Brussels, Belgium; e-mail: tim.adriaens@instant.be \\ ${ }^{3}$ Institute of Animal Ecology, Ghent University, Ledeganckstraat 35, B-9000 Ghent, Belgium; e-mail: Henri.Dumont@rug.ac.be \\ ${ }^{4}$ Laboratory of Aquatic Ecology, University of Leuven (KU Leuven), De Bériotstraat 32, B-3000 Leuven, Belgium; \\ e-mail: Robby.Stoks@bio.kuleuven.ac.be
} Key words. Behaviour, colour, Odonata, Enallagma cyathigerum, damselfly, detection, polymorphism, andro-, gynomorphs,
predation, survival

\begin{abstract}
The coexistence of discrete morphs within a species, with one morph more conspicuous than the other(s) is often thought to result from both sexual selection and predation. In many damselflies, sexual dimorphism occurs jointly with multiple female colour morphs. Typically, one morph is coloured like the male (andromorph), while the other(s) is not (gynomorph(s)). The mechanisms contributing to the maintenance of such female polymorphism in damselflies remain poorly understood, especially the role of predation. We tested the detectability of two different female colour morphs of the damselfly, Enallagma cyathigerum, using human observers as model predators; andromorphs were detected more frequently than gynomorphs. Field data on mortality of males and the two different female morphs due to predation or drowning were also collected, and these observations support morph-specific mortality. In natural populations predation risk was higher in males than females; gynomorphs, however, were more prone to predation than andromorphs. Differences in behaviour between morphs, rather than colour, may explain this result.
\end{abstract}

\section{INTRODUCTION}

Predation is an important variable in models of natural and sexual selection and one of the main forces causing differences in fitness among phenotypes (e.g. Endler, 1986; Krebs \& Davies, 1997). When phenotypes are discrete and differ in conspicuousness, predation may contribute to survival differences among groups, which result in a population in which one morph is far more frequent than the other morph(s) (Bond \& Kamil, 2002). Among groups showing discrete phenotypic differences associated with sex, males are mostly more conspicuous than females (e.g. Andersson, 1994). Less thoroughly studied are discrete differences associated with polychromy within one sex, such as encountered in many female damselflies (e.g. Fincke, 1994).

In spite of a series of studies, the evolution and maintenance of female-limited colour polymorphism in damselflies remains puzzling (e.g. Fincke, 1994; Cordero et al., 1998; Andrés et al., 2000; Andrés \& Cordero, 2001; Sherratt, 2001). Typically, one of the female colourmorphs (andromorph) is a male mimic, in some species even patterned like the male, while other morphs (gynomorphs) are not (e.g. Corbet, 1999). Andromorphs are thought to possess a selective advantage, viz. the ability to avoid male harassment (e.g. Johnson, 1975; Robertson, 1985; Cordero et al., 1998; Sherratt, 2001); according to another view this idea only holds when andromorphs are the least common female morph (Fincke, 1994; Van Gossum et al., 2001). Some studies have proposed that this benefit may be compensated for by the more efficient detection and capture by visual predators of the conspicuous andromorphs rather than the cryptic gynomorphs (Johnson, 1975; Robertson, 1985). Although the role of body colouration in damselflies in attracting predators has been questioned (Cordero et al., 1998; Andrés \& Cordero, 2001), evidence to test this idea is lacking.

Van Gossum et al. (2004), using humans as predator models, did not find differences in the probability of detecting the different female colour morphs in the damselfly Ischnura elegans (Vander Linden, 1820) in experiments where female morph behaviour was excluded. Forbes (1994) did not find a differential predation of copulating females of the damselfly Enallagma boreale (Selys, 1875) by dragonflies. However, in his experiment either the copulating male or the female were alive, hence it cannot be excluded that detection was influenced by the behaviour of the animals in this study and/or attraction by the predator to the male solely.

Several researchers have studied the potential cost of predation by comparing the survival of morphs (either males versus females or between morphs within one sex) in the field (e.g. Forsman \& Appelqvist, 1999, for polychromic grasshoppers). Results from field studies on damselflies using traditional capture-mark-recapture models (Seber, 1982) showed equal life spans for males and females (e.g. Hafernik \& Garrison, 1986; Cordero, 1995) and for andro- and gynomorphs (e.g. Thompson, 1989; Fincke, 1994; Cordero et al., 1998). Studies using

* Present address: Department of Biology, Carleton University 1125 Colonel By Drive, Ottawa, K1S 5B6 Ontario, Canada; e-mail: Hans.VanGossum@ua.ac.be 
advanced capture-mark-recapture models (Lebreton et al., 1992), which allow separation of the estimates of survival and recapture rates, also did not reveal morph-specific differences in survival (Van Gossum, 1997; Andrés \& Cordero, 2001). Nonetheless, survival is dependent on many factors other than predation, such as dehydration, starvation, parasites and disease (see Discussion and Fig. 1). Hence, comparison based on survival is unlikely to be suitable for testing the hypothesis of Johnson (1975) and Robertson (1985) (see Discussion and Fig. 1) that andromorphs are more prone to predation by visual predators.

In this study we experimentally test the hypothesis that colouration makes andromorphs easier to detect than gynomorphs in the damselfly, Enallagma cyathigerum (Charpentier, 1840). Furthermore, we use observations of predation in the field to determine whether males or females and andromorphs or gynomorphs suffer more mortality due to predation and/or drowning. We examine whether human predators are representative of the natural predator guild of this damselfly and discuss the use of survival probabilities to test for differences in predation between female morphs.

\section{MATERIAL AND METHODS}

\section{Study species}

The damselfly $E$. cyathigerum has one male and two distinct female morphs. Males have conspicuous light blue (especially abdominal segments eight and nine) body markings on a black background. Andromorphs have a similar conspicuous colour pattern but with more black on the abdomen and a darker blue than males. Gynomorphs, in contrast, show yellow to brownish body markings and have a cryptic body colouration compared to andromorphs and males.

\section{Are andromorphs easier to detect than gynomorphs (based} on differences in body colouration between morphs)?

In an experiment with dead females we tested whether human observers detect andromorphs easier than gynomorphs. Human observers were not colour blind and between 17 and 30 years old. Older observers were avoided because with age humans become less sensitive to shorter wavelengths (Wyszecki \& Stiles, 1982). We performed experiments with 46 naïve human observers and dead damselflies between 9 and $16 \mathrm{~h}$ in "De Biotuin" (Belgium, Antwerp; 24 observers) on 14 July 1999 and at "Meibosvijvers" (Belgium, Damme; 22 observers) on 13 August 2000. Experimental damselflies were collected from populations in Kalmthout and Zevenkerke (Belgium), where both colour morphs are abundant, one day before the experiment. To exclude the effect of behavioural differences between morphs, and to test for differences in detection due to colour, damselflies were killed in chloroform one hour before the experiment. The experiment was conducted at ponds with small resident populations. Human observers were asked to walk a track with twelve stops, each marked by a wooden stick, in the company of one of the authors (TA). The sticks guided the observers to the "predation" sites. At each stick, within a radius of $0.5 \mathrm{~m}$, one dead andromorph and one dead gynomorph were glued to stems or leaves by means of a drop of instant glue on its legs and abdomen. Care was taken to position animals in a natural and random way. Therefore, we selected two comparable locations within the radius before randomly attaching the two morphs. Damselflies were glued at a height of $20-90 \mathrm{~cm}$, in an upright position.

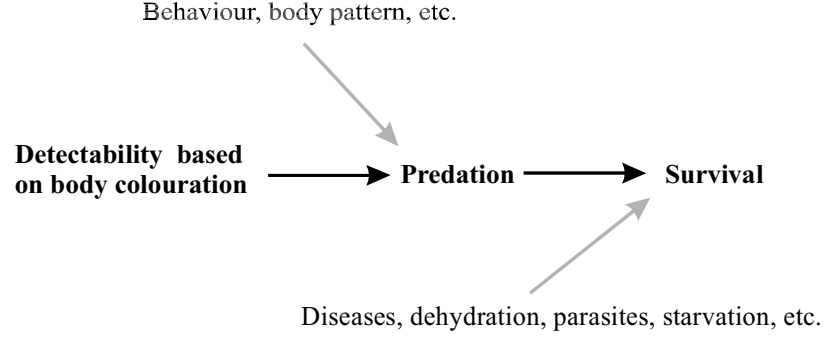

Fig. 1. Factors that may affect the differences in survival of the colour morphs. The black arrows represent the hypothesis that Johnson (1975) and Robertson (1985) use to explain the lower survival of the conspicuously coloured andromorphs compared to the more cryptic gynomorphs. The first step in this hypothesis was experimentally tested in the present article. The grey arrows indicate other, potentially confounding, factors that may contribute to selective predation and/or survival but were not considered by Johnson (1975) and Robertson (1985).

Each observer was asked to squat at each stick and examine the area for insects, without touching the vegetation. Scanning was confined to an area of $0.5 \mathrm{~m}$ radius from the stick. Preliminary tests showed that when the radius was larger, search time increased considerably, and/or observers failed to find the animals. After detection of one damselfly or after a maximum search time of thirty seconds, the observer was asked to move to the next site and repeat the search until all sites had been visited. Observers only knew that they had to search for dead insects. They were not given information concerning species, colour patterns, number of animals hidden or aim of the study. Consequently, during the first encounter observers were inexperienced with the prey species. In field conditions, predators are usually experienced and search for a particular prey species (Krebs \& Davies, 1997). Thus, repeating the search sessions using the same observer, by moving from stick to stick, mimics the increasing experience of natural predators hunting for prey.

To test for differences in detectability between morphs we performed a repeated measure logistic regression with the detected morph (gynomorph $=0$; andromorph $=1$ ) as dependent variable. Since subsequent observations by the same person are not statistically independent they were treated as repeated measures. Study site was included in the analysis to test for differences between locations. The sticks were nested in study site. Several covariance structures were modelled, but they all gave identical results (we used a covariance structure modelled as autoregressive order one). To account for differences in morph detectability between sticks, "stick" was added to the model as a random variable (GLIMMIX macro SAS 8.02; Littell et al., 1996). We tested (one-sided) whether 1) andromorphs are more conspicuous than gynomorphs and 2) this conspicuousness increased during the course of the experiment (stick number as fixed effect). Degrees of freedom were obtained by the Satterthwaite formula.

\section{Do the sexes and female morphs differ in predation risk?}

We examined whether sexes and female morphs differ in susceptibility to predation and/or drowning. To test for differential mortality between groups one needs to correct for their relative frequency in populations. Therefore, we monitored predation events as well as operational sex (proportion of males in the population) and female morph ratio (proportion of andromorphs in the population). Predation and morph ratios were studied in twelve populations at fens in northern Belgium between 15 and 26 July 1999. Along the shoreline of each fen (population), two transects, 20 meters long and five meters wide, were marked by 
TABLE 1. Mortality observed in the field of males, and andro- and gynomorph females of the damselfly E. cyathigerum.

\begin{tabular}{lcccccrr}
\hline & \multicolumn{7}{c}{ Mortality due to predation by } \\
\cline { 2 - 8 } & robberflies & spiders & sundew & dragonflies & frogs & drowning & Total \\
\hline Males & 3 & 140 & 8 & 3 & 1 & 11 & 166 \\
Andromorphs & 0 & 2 & 0 & 0 & 0 & 2 & 4 \\
Gynomorphs & 0 & 24 & 1 & 0 & 0 & 17 & 42 \\
Total & 3 & 166 & 9 & 3 & 1 & 30 & 212 \\
\hline
\end{tabular}

wooden sticks. Transects were a minimum of thirty meters apart and consisted of a land and a water portion. Estimates of sex ratio and morph ratio were obtained by slowly walking along transects, counting all animals by eye or using binoculars (Opticron, $10 \times 50$ ). The experience of the authors resulted in a search image that did not rely solely on body colouration for detecting resting or flying damselflies (personal observation). Hence, an absence of differences in detection between androand gynomorphs is assumed. Three populations (six transects) per day were sampled. Each population was sampled once. Sex and morph of every animal encountered were noted. If a dead animal was found, the cause of death (predation, drowning...) was identified whenever possible. Predators could be assigned to species if the predator was found consuming prey or when a damselfly was trapped in a spider's web.

Differences in mortality between males and females, and between andromorphs and gynomorphs were analysed using Fisher's Exact test correcting for sex ratio and for morph ratio (StatXact 3: Mehta \& Patel, 1995).

\section{RESULTS}

\section{Are andromorphs easier to detect than gynomorphs?}

Overall mean detectability was higher for andromorphs $(62 \%)$ than for gynomorphs $(38 \%)(\mathrm{t}=2.00 ; \mathrm{df}=19.3 ; \mathrm{p}$ $=0.030)$. The detection probability of andromorphs relative to gynomorphs did not differ between study sites $\left(\mathrm{F}_{1,18.5}=0.05 ; \mathrm{p}=0.83\right)$ and in the majority $(75 \%)$ of cases, a damselfly was detected at each stick $(\mathrm{N}=552)$. There was a slight increase in the probability of detecting a particular morph with the number of sticks visited $\left(\mathrm{F}_{1,17.6}=1.95 ; \mathrm{p}=0.090\right)$.

\section{Do both sexes and female morphs differ in predation risk?}

Populations differed in the proportion of males to females (one-way ANOVA with population as independent variable and proportions of each sex counted at both transects as replicates, $F_{11,12}=7.12, p=0.001$ ). All populations were male-biased and differences between populations were small (mean: $0.844 \mathrm{SE}$ : 0.027; range: $0.667-0.941$ ). The average proportion of andromorphs to gynomorphs was also comparable for all populations (one-way ANOVA, $\mathrm{F}_{11,12}=0.55, \mathrm{p}=0.83$; mean: 0.210 SE: 0.030; range: $0.060-0.352$ ). Given the above and that predation events were too scarce to be analysed per population, we combined them and used the average sex ratio and morph ratio as a reference situation to evaluate sex or morph bias in predation.

In all, 212 dead animals were found, of which 182 $(85.8 \%)$ could be assigned to predation. Spiders accounted for $78 \%$ of the predation; ten species, in five families, were involved, with Araneidae and Tetrag- nathidae being the most abundant (respectively $74.8 \%$ and $13.0 \%$ ). Other predators included dragonflies, frogs, robberflies and the carnivorous plant, sundew (Table 1). Drowning was the other source of mortality (Table 1). Overall mortality was higher in males (166 deaths recorded) than in females (46) taking into account the average sex ratio (Fisher Exact, $\mathrm{df}=1, \mathrm{p}<0.001$ ) (Table 1). After correcting for the average proportion of andromorphs to gynomorphs, observed overall mortality was higher in gynomorphs (42) than in andromorphs (4) (Fisher Exact, $\mathrm{p}=0.016$ ) (Table 1). Excluding mortality caused by drowning, mortality by predation was also higher in males (155) than in females (27) (corrected for average sex ratio; Fisher Exact, $\mathrm{p}<0.001)$ and in gynomorphs (25) than in andromorphs (2) (corrected for average morph ratio; Fisher Exact, $d f=1, p=0.026)$. It follows from the above that mortality in males was higher than in the, similarly coloured, female andromorphs.

\section{DISCUSSION}

Consistent with the idea that males are more conspicuous than females we found a higher mortality due to predation in males of E. cyathigerum (see also Fincke, 1994; Götmark \& Hohlfält, 1995). Although this should produce a higher proportion of females in the population, population sex ratios of adult males and females are mostly male-biased (Garrison \& Hafernik, 1981; Fincke, 1982; Hamilton \& Montgomerie, 1989; Anholt, 1997; Stoks, 2001a, b). Apparently, a selective force other than predation has a stronger effect on female than on male survival. Unfortunately, any selective pressure exercised by, for example, birds might have gone unnoticed because the presence of humans diminishes that of birds at a field site (Andrés \& Cordero, 2001). We were only able to record mortality by predation if a predator was caught in the act of consuming prey. Therefore, our results may be biased towards particular predator species. Nonetheless, our observations (Table 1) include the important predators of damselflies (Rehfeldt, 1995).

Experimental support is provided for humans finding it easier to detect andromorphic females than gynomorphs in E. cyathigerum. This supports the argument of Johnson (1975) and Robertson (1985) that andromorphs are more vulnerable to predation. It should be pointed out that these authors implicitly base their hypothesis on a human perception of the situation. Using human 'predators' can, indeed, give interesting insights into poorly understood ecological mechanisms (e.g. Götmark \& Hohfält, 1995; Glanville \& Allen, 1997; Van Damme \& Van Dooren, 1999; Cuadrado et al., 2001; Sherratt \& Beatty, 2003). 
Moreover, the use of human models is not only profitable in terms of the flexibility of the participants, they also have few preconceptions concerning the profitability of encountered prey items (e.g. Riipi et al., 2001). Furthermore, at least dragonflies and birds are known to have excellent vision and the ability to develop a search image (e.g. Corbet, 1999; Bond \& Kamil, 2002). Together, some groups of predators may be very similar to humans in detecting damselflies and may have a similar detection bias towards andromorphs.

Our field observations provide evidence for morphspecific predation on female E. cyathigerum. However, they are at variance with the human observer-based prediction of a higher predation on the more conspicuous andromorphs (Johnson, 1975; Robertson, 1985; this study), as we recorded a higher predation on gynomorphs. Because we corrected for morph ratio, this difference is not attributable to a skewed ratio in the field. Thus morph-specific detectabilities based on what humans observe do not necessarily translate into differential morph-specific predation in the field. Two factors may explain this discrepancy. First, spiders, waterstriders, water scorpions, wasps, diving beetles, robberflies and frogs also predate on adult damselflies (Parr \& Parr, 1972; Johnson, 1975; Fincke, 1994; Rehfeldt, 1995; Stoks \& De Bruyn, 1996; Corbet, 1999). Web spiders (Larochelle, 1978; Rehfeldt, 1995; Cordero et al., 1998) use ambush tactics but some other spiders actively search for prey (e.g. Thomisidae, Pisauridae, Salticidae) and are able to distinguish between prey types (e.g. Jackson \& Li, 1998). Frogs are unselective, attacking any moving object (e.g. Michiels \& Dhondt, 1990). From our study it is clear that web spiders, which do not rely on body colouration to catch prey, are responsible for the majority of the predation events on Enallagma cyathigerum. Second, androand gynomorphs also differ in activity, in mating avoidance tactics and in habitat use (e.g. Robertson, 1985; Forbes et al., 1995; Sirot, 1999; Van Gossum et al., 2001). Gynomorphs hide more among vegetation, fly longer distances and fly away when approached by a male, while andromorphs use more open habitat, do not fly great distances and face-off approaching males (Sirot, 1999; Van Gossum et al., 2001). Furthermore, and for similar reasons, Rehfeldt (1992) found that males of territorial damselflies are more often trapped in spider webs than are non-territorial ones. Together these observations indicate that different morphs may suffer different mortalities as a consequence of their behaviour and use of microhabitat. Indeed, if gynomorphs fly more, and particularly fly more in vegetation, they will be more vulnerable to being caught in spider webs and by carnivorous plants, or simply drowning (Table 1). Although we recorded predation by several types of predators, we cannot rule out that other predators remained unnoticed, as in the case of birds discussed above (see Andrés \& Cordero, 2001). Hence, although the importance of differences in morph colouration cannot be excluded, morph behaviour may be a better predictor of predation risk. Evidently, differences in predation risk may also result from a combination of colour and behaviour. The challenge of future studies on differential predation risk therefore lies in manipulating morph colouration and morph behaviour independently.

Some researchers use survival probabilities of morphs to study the potential cost of predation (e.g. Cordero et al., 1998). Capture-mark-recapture models, however, only generate survival probabilities, and do not provide information on the mechanisms shaping these probabilities. Therefore, we question whether survival probabilities provide information on the probability of detection. As for insects in general, mortality in damselfly populations can be caused by carnivores, parasites and disease; interactions with conspecifics, dehydration and starvation (Fig. 1; Corbet, 1999). If morph-specific differences in survival are absent, it implies that andro- and gynomorphs suffer equally from the sum of all these mortality factors, although there may be significant differences in the respective contributions of each. In other words, equal (or unequal) survival probabilities among morphs do not necessarily explain differences in mortality due to predation or to the probability of detection (Andrés \& Cordero, 2001). That other mechanisms besides predation are at work in shaping survival in female damselflies is supported by an experiment with I. elegans in which survival differences between female morphs occurred when cannibalism and predation were excluded (Van Gossum, 2001).

ACKNOWLEDGEMENTS. HVG and RS are postdoctoral fellows with the Fund for Scientific Research-Flanders (FWO). We are grateful to L. De Bruyn for advice and assistance with statistical analysis and to D. Bonte for verifying spider determinations.

\section{REFERENCES}

Andrés J.A. \& Cordero A. 2001: Survival rates in a natural population of Ceriagrion tenellum (Villers): effects of sex and female phenotype. Ecol. Entomol. 26: 341-346.

Andrés J.A., SANChez-Guillen R.A. \& Cordero A.C. 2000: Molecular evidence for selection on female color polymorphism in the damselfly Ischnura graellsii. Evolution 54: 2156-2161.

Andersson M. 1994: Sexual Selection. Princeton University Press, Princeton, 624 pp.

Anholt B.R. 1997: Sexual size dimorphism and sex-specific survival in adults of the damselfly Lestes disjunctus. Ecol. Entomol. 22: 127-132.

Bond A.B. \& KamiL A.C. 2002: Visual predators select for crypticity and polymorphism in virtual prey. Nature 415: 609-613.

Corbet P.S. 1999: Dragonflies: Behaviour and Ecology of Odonata. Harley Books, Essex, 829 pp.

Cordero A. 1995: Correlates of male mating success in two natural populations of the damselfly Ischnura graellsii (Odonata: Coenagrionidae). Ecol. Entomol. 61: 769-780.

Cordero A., Carbone S.S. \& Utzeri C. 1998: Mating opportunities and mating costs are reduced in androchrome female damselflies, Ischnura elegans (Odonata). Anim. Behav. 55: 185-197.

Cuadrado M., Martin J. \& Lopez P. 2001: Camouflage and escape decisions in the common chameleon Chamaeleo chamaeleon. Biol. J. Linn. Soc. 72: 547-554. 
Endler J.A. 1986: Natural Selection in the Wild. Princeton University Press, Princeton, $354 \mathrm{pp}$.

FINCKE O.M. 1982: Lifetime mating success in a natural population of the damselfly Enallagma hageni (Walsh) (Odonata: Coenagrionidae). Behav. Ecol. Sociobiol. 10: 293-302.

FINCKE O.M. 1994: Female colour polymorphism in damselflies: failure to reject the null hypothesis. Anim. Behav. 47: $1249-1266$.

FoRBES M.R.L. 1994: Tests of hypotheses for female-limited polymorphism in the damselfly, Enallagma boreale Selys. Anim. Behav. 47: 724-726.

Forbes M.R.L., Richardson J.M.L. \& BaKer R.L. 1995: Frequency of female morphs is related to an index of male density in the damselfly, Nehalennia irene (Hagen). Ecoscience 2: $28-33$.

Forsman A. \& ApPelqvist S. 1999: Experimental manipulation reveals differential effects of colour pattern on survival in male and female pygmy grasshoppers. J. Evol. Biol. 12: 391-401.

GARRISON R.W. \& HAFERNIK J.E. 1981: Population structure of the rare damselfly Ischnura gemina (Kennedy) (Odonata: Coenagrionidae). Oecologia 48: 377-384.

Glanville P.W. \& AlLEN J.A. 1997: Protective polymorphism in populations of computer-simulated moth-like prey. Oikos 80: $565-571$

GötMARK F. \& HoHLFËLt A. 1995: Bright male plumage and predation risk in passerine birds: are males easier to detect than females? Oikos 74: 475-484.

HAFERNIK J.E. \& GARRISON R.W. 1986: Mating success and survival rate in a population of damselflies: results at variance with theory? Am. Nat. 128: 353-365.

Hamilton L.D. \& Montgomerie R.D. 1989: Population demography and sex ratio in a neotropical damselfly (Odonata: Coenagrionidae) in Costa Rica. J. Tropical Ecol. 5: 159-171.

JACKSON R.R. \& LI D.Q. 1998: Prey preferences and visual discrimination ability of Cyrba algerina, an araneophagic jumping spider (Araneae: Salticidae) with primitive retinae. Israel J. Zool. 44: 227-242.

JoHNSON C. 1975: Polymorphism and natural selection in ischnuran damselflies. Evol. Theory 1: 81-90.

Krebs J.R. \& Davies N.B. 1997: Behavioural Ecology: An Evolutionary Approach. $4^{\text {th }}$ edn. Blackwell Science, Oxford, 464 pp.

LAROChelle A. 1978: Spiders as predators and prey of Odonata. Cordulia 4: 29-34.

Lebreton J.D., Burnham K.P., Clobert J. \& Anderson D.R. 1992: Modelling survival and testing biological hypotheses using marked animals: a unified approach with case studies. Ecol. Monogr. 62: 67-118.

Littell R.C., Milliken G.A., Stroup W.W. \& Wolfinger R.D. 1996: SAS System for Mixed Models. Cary, NC: SAS Institute Inc.

Menta C. \& Patel N. 1995: StatXact 3 for Windows, User Manual. Cambridge: CYTEL Software.

Michiels N.K. \& Dhondt A.A. 1990: Costs and benefits associated with oviposition site selection in the dragonfly Sympetrum danae (Odonata: Libellulidae). Anim. Behav. 40: 668-678.
Parr M.J. \& Parr M. 1972: Survival rates, population density and predation in the damselfly, Ischnura elegans (Vander Linden) (Zygoptera: Coenagrionidae). Odonatologica 1: 137-141.

REHFELDT G.E. 1992: Impact of predation by spiders on a territorial damselfly (Odonata: Calopterygidae). Oecologia 89: 550-556.

Rehfeldt G.E. 1995: Naturliche Feinde, Parasiten und Fortplanzung von Libellen. Odonatological monographs 1, University of Braunschweig, $210 \mathrm{pp}$.

Riipi M., Alatalo R.V., Lindström L. \& Mappes J. 2001: Multiple benefits of gregariousness cover detectability costs in aposematic aggregations. Nature 413: 512-514.

RoBERTSON H.M. 1985: Female dimorphism and mating behaviour in a damselfly, Ischnura ramburi: females mimicking males. Anim. Behav. 33: 805-809.

Seber G.A.F. 1982: The Estimation of Animal Abundance. Charles Griffin, London, 654 pp.

SherRATT T.N. 2001: The evolution of female-limited polymorphisms in damselflies: a signal detection model. Ecol. Letters 4: 22-29.

SherRatt T.N. \& Beatty C.D. 2003: The evolution of warning signals as reliable indicators of prey defense. Am. Nat. 162: 377-389.

Sirot L. 1999: Intersexual Conflict and Mating Avoidance in the Damselfly, Ischnura ramburi. MSc thesis, University of Florida, $65 \mathrm{pp}$.

Stокs R. 2001a: Male-biased sex ratios in mature damselfly populations: real or artefact? Ecol. Entomol. 26: 181-187.

Stoks R. 2001b: What causes male-biased sex ratios in mature damselfly populations? Ecol. Entomol. 26: 188-197.

Stoks R. \& De Bruyn L. 1996: Intensive feeding of the robberfly Eutolmus rufibarbis (Diptera: Asilidae) on the damselflies Enallagma cyathigerum and Lestes sponsa (Odonata). Bull. Annls Soc. R. Belge Entomol. 132: 427-431.

THOMPSON D.J. 1989: Lifetime reproductive success in andromorph females of the damselfly Coenagrion puella (Zygoptera: Coenagrionidae). Odonatologica 18: 209-213.

Van Damme R. \& Van Dooren T.J.M. 1999: Absolute versus per unit body length speed of prey as an estimator of vulnerability to predation. Anim. Behav. 57: 347-352.

Van Gossum H. 1997: Inleidende Eco-Ethologische Studie van Ischnura elegans. Licenciaatsthesis, University of Antwerp, $110 \mathrm{pp}$.

Van Gossum H. 2001: Evolutionary Ecology of Female Colour Polymorphism in a Damselfly. PhD. thesis, University of Antwerp, $115 \mathrm{pp}$.

Van Gossum H., Stoks R. \& De Bruyn L. 2001: Frequencydependent male harassment and intra-specific variation in its avoidance by females of the damselfly Ischnura elegans. Behav. Ecol. Sociobiol. 51: 69-75.

Van Gossum H., Stoks R. \& De Bruyn L. 2004: Conspicuous body coloration and predation risk in damselflies: are andromorphs easier to detect than gynomorphs? Belg. J. Zool. (in press).

Wyszecki G. \& Stiles W.S. 1982: Colour Science: Concepts and Methods, Quantitative Data and Formulae. Wiley, New York, $935 \mathrm{pp}$.

Received May 28, 2003; revised December 12, 2003; accepted April 21, 2004 